\section{(2) OPEN ACCESS}

\title{
A complex DICER1 syndrome phenotype associated with a germline pathogenic variant affecting the RNase Illa domain of DICER1
}

\author{
Emeli Pontén (D) ,' Sofia Frisk, ${ }^{1,2}$ Fulya Taylan (D) , ${ }^{1,2}$ Raquel Vaz, ${ }^{1}$ Sandra Wessman, ${ }^{3}$ \\ Leanne de Kock (D) , ${ }^{4}$ Niklas Pal, ${ }^{5}$ William D Foulkes (D) ${ }^{4}$ \\ Kristina Lagerstedt-Robinson (D) , ${ }^{1,2}$ Ann Nordgren (iD) 1,2
}

- Additional material is published online only. To view, please visit the journal online (http://dx.doi.org/10.1136/ jmedgenet-2020-107385).

'Department of Molecular Medicine and Surgery (MMK), Karolinska Institute, Stockholm Sweden

${ }^{2}$ Clinical Genetics, Karolinska University Hospital, Stockholm, Sweden

${ }^{3}$ Oncology-Pathology, Karolinska University Hospital, Stockholm, Sweden

${ }^{4}$ Departments of Human Genetics, Oncology, Medicine, McGill University, Montreal, Québec, Canada

${ }^{5}$ Department of Pediatric Oncology, Karolinska University Hospital, Stockholm, Sweden

\section{Correspondence to}

Professor Ann Nordgren, Dept of Molecular Medicine and Surgery (MMK), Karolinska Institute, 171 64 Stockholm, Sweden; ann.nordgren@ki.se

$\mathrm{KL}-\mathrm{R}$ and $\mathrm{AN}$ are joint senior authors.

Received 5 August 2020

Revised 10 October 2020 Accepted 12 October 2020
Check for updates

(C) Author(s) (or their employer(s)) 2020. Re-use permitted under CC BY. Published by BMJ.

To cite: Pontén E, Frisk S, Taylan F, et al. J Med Genet Epub ahead of print: [please include Day Month Year]. doi:10.1136/

jmedgenet-2020-107385

\begin{abstract}
Background Germline pathogenic variants in DICER 1 cause DICER1 syndrome, an autosomal dominant, pleiotropic tumour predisposition syndrome with variable expressivity and reduced penetrance for specific dysplastic and neoplastic lesions. Recently, a syndrome with the acronym GLOW (Global developmental delay, Lung cysts, Overgrowth, Wilms tumour) was described in two children with mosaic missense mutations in hotspot residues of the DICER1 RNase Illb domain.

Methods Whole genome sequencing, exome sequencing, Sanger sequencing, digital PCR and a review of Wilms tumours with DICER1 RNase III domain mutations were performed.
\end{abstract}

Results A de novo heterozygous c.4031C>T (p.S1344L) variant in the sequence encoding the RNase Illa domain of DICER 1 was detected. Clinical investigations revealed a phenotype that resembles the GLOW subphenotype of DICER1 syndrome.

Conclusion The phenotypic overlap between patients with p.S1344L mutation and GLOW syndrome provide clinical support for recent discoveries that RNase IIlaSer1344 site mutations impede miRNA-5p biogenesis analogous to DICER 1 hotspot mutations in the RNase IIIb domain. We show that an individual with a heterozygous germline p.S1344L mutation has a severe form of DICER1 syndrome ('DICER1 syndrome plus'), with notable features of intellectual disability, macrocephaly, physical abnormalities, Wilms tumour and a well-differentiated fetal adenocarcinoma of the lung.

\section{INTRODUCTION}

The DICER1 (MIM *606241) gene located at $14 \mathrm{q} 32.13$ is important for embryogenesis and early somatic development. Residing in the cytoplasm, the DICER1 protein is an endoribonuclease (RNase) III cleaving double-stranded RNA. The enzyme is crucial for producing miRNAs, as it processes precursor strands (pre-miRNA) whereby two single-stranded miRNA molecules are produced, named by their prime end origin ( $3 \mathrm{p} / 5 \mathrm{p}$ miRNA). ${ }^{1}$

DICER1 syndrome (MIM \#601200) is an autosomal dominant, pleiotropic tumour predisposition syndrome with variable expression and reduced penetrance of benign and malignant tumours, commonly pleuropulmonary blastoma (PPB), cystic nephroma, Sertoli-Leydig cell tumour and hyperplastic proliferations such as multinodular goitre. The most frequently observed mechanism underlying tumour formation in DICER1 syndrome is the presence of biallelic alterations that include germline loss of function (LOF) pathogenic variants, combined with somatic in trans mutations in the sequence encoding the hotspot residues of the RNase IIIb domain. ${ }^{12}$

Missense mutations occurring in exons encoding the DICER1 RNase IIIb domain, either involving or adjacent to catalytically active metal-ion binding residues including p.E1705, p.D1709, p.G1809, p.D1810, p.E1813 and p.D1713 are recognised as cancer hotspot loci. Alterations of these RNase IIIb residues cause neomorphic alleles, reported to be functionally equivalent with respect to miRNA biogenesis. ${ }^{2}$ These alterations interfere with the canonical processing of miRNA precursors, resulting in a relative excess of $3 p$-miRNA and a depletion of $5 \mathrm{p}$-miRNA. ${ }^{3}$ It has recently been revealed through evolutionary and structural coupling analyses that RNase IIIa-S1344 site is in close proximity to the active cleft of RNase IIIb domain and that a mutation in RNase IIIa-S1344 exhibit the same pattern of $5 \mathrm{p}$-miRNA loss as that resulting from RNase IIIb hotspot mutations. ${ }^{4}$ In 2014, Klein et al proposed a new DICER1 related syndrome with the acronym GLOW (Global developmental delay, Lung cysts, Overgrowth, Wilms tumour), describing two children with mosaic missense hotspot mutations in DICER1 affecting the RNase IIIb domain. A highly penetrant and severe phenotype has been shown in patients with mosaic ${ }^{56}$ or germline ${ }^{7}$ RNase IIIb mutations, compared with patients with classic DICER1 syndrome caused by germline LOF pathogenic variants.

Here, we show evidence that the germline c. $4031 \mathrm{C}>\mathrm{T}$ (p.S1344L) mutation in DICER1 causes a severe subtype of DICER1 syndrome with intellectual disability (ID), macrocephaly, extensive bilateral lung cysts, early onset of Wilms tumour and well-differentiated fetal lung adenocarcinoma-a clinical spectrum similar to, but distinct from, the phenotype reported in two patients with GLOW syndrome with postzygotic hotspot mutations in exons encoding the RNase IIIb domain. 

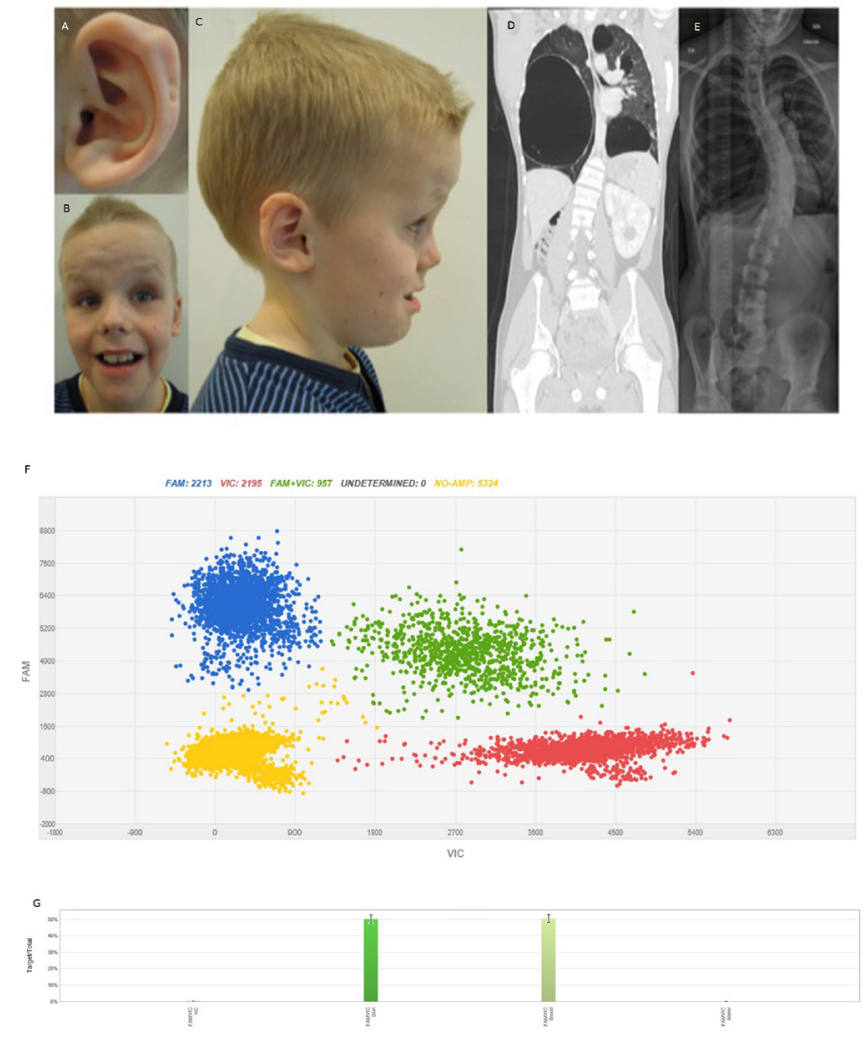

Figure 1 Patient characteristics. Photographs of the patient at 10.5 years of age showing (A) posterior ear pits of left helix, (B) a high, broad, furrowed forehead, mild hypertelorism, short, upturned nose, facial nevi, large mouth and teeth, $(C)$ profile portrait of the patient showing macrocephaly and posterior ear pits of the right helix. (D) CT scan of the patient at 16 years of age showing bilateral large cysts and a cystic nephroma in the remaining enlarged kidney. (E) Chest X-ray of the patient at 16 years of age showing left convex thoracic scoliosis. (F) dPCR results of DNA from skin biopsy from the patient. Blue cluster represents amplification of the target region - the mutant allele c.4031C >T. Red signals represent the internal reference control and green signals both mutant and reference alleles. Yellow cluster represents the wells where no amplification signal was detected. (G) Mutant frequency comparison. $X$-axis and Y-axis show the intensities of signals VIC and FAM channels. Columns display the distribution of $50 \%$ of the c.4031C > T variant in DNA from skin and blood from the patient. Left column—skin, right column—peripheral blood.

\section{MATERIALS AND METHODS \\ Methods}

Genomic DNA was extracted from peripheral blood, skin, saliva, oral mucosa, fresh tumour tissue and formalin-fixed, paraffinembedded tumour tissue using standard protocols. DNA from both parents was extracted from peripheral blood.

\section{Sequencing and bioinformatic analysis}

Standard 30x whole genome sequencing (WGS), exome sequencing (ES) and bioinformatic analysis were performed at Clinical Genomics, SciLifeLab, Stockholm, using the Illumina HiSeq X Ten platform. Single nucleotide variants were called using Mutation Identification Pipeline. Variants were filtered, removing variants with a frequency over $1 \%$ in the general population. ${ }^{8}$ A constructed gene panel based on HPOterms (Macrocephaly HP:0000256, Polydactyly HP:0010442,
Nephroblastoma HP:0002667) consisting of in total 476 genes were analysed regarding variants affecting coding regions or splicing (online supplemental table 1). The clinically relevant sequence variant was verified in the patient using Sanger sequencing. Carrier testing of the parents was performed using Sanger sequencing.

\section{Digital PCR}

Genomic DNA extracted from blood, skin, saliva and oral mucosa were amplified using 1X QuantStudio 3D Digital PCR Master mix and commercially available TaqMan assay for DICER1 c.4031C > T mutation (Applied Biosystems, California, USA). DNA was quantified using Qubit fluorometry (Thermo Fisher Scientific, Massachusetts, USA). Then $14.6 \mu \mathrm{L}$ of PCR reaction mixes were loaded into QS3D Digital 20K V2 chips (Applied Biosystems). Protocol was followed as previously described. ${ }^{9}$ Digital PCR data were analysed using PoissonPlus algorithm (V.4.4.10) with a 95\% CI and a desired precision of 10\% by QuantStudio 3D AnalysisSuite (V.3.1.2-PRC-build-03).

\section{RESULTS \\ Clinical description}

The patient is the first child from healthy, non-consanguineous parents with unremarkable family history. He was born at gestational week 39 after a difficult delivery due to macrocephaly (Apgar 1-3-7). The birth weight was $3752 \mathrm{~g}$, length $53 \mathrm{~cm}$ and head circumference $42 \mathrm{~cm}$ (>99th percentile). Clinical findings at birth included two blood vessels in the umbilical cord, undescended testis, inguinal hernia, postaxial polydactyly, ear pits and rocker bottom feet. Fontanel closure was late and he had difficulties breast feeding. At 15 months of age, he was diagnosed with a right-sided Wilms tumour (classic triphasic nephroblastoma with all three classic histological elements). Abdominal ultrasound also revealed a cyst of benign appearance in his left kidney. A lung scan showed multiple large cysts and a suspected Wilms tumour metastasis. A lobectomy of the middle lobe was performed to remove the tumour and three cysts. Owing to suspicion of additional metastasis, another thoracotomy was performed and two cysts in the right lower lobe were removed. The five removed lung cysts were diagnosed as benign fibrotic emphysematous alterations with bullous, cystic character. The pathologic-anatomic diagnosis of the lesion in the middle lobe was initially Wilms tumour metastasis, but following the identification of the pathogenic germline DICER1 variant, pathology review determined that the correct diagnosis was well-differentiated fetal adenocarcinoma. Re-examination of radiographic findings, also after the DICER1 syndrome diagnosis, revealed a suspicion of a multiloculated cystic nephroma in the remaining kidney. The patient received postoperative chemotherapy and has been tumor-free since 2006. He had a late psychomotor development, started to walk at 3 years of age and spoke full sentences at 5 years. MRI of the brain was performed at 12 years of age and revealed signs of white matter reduction including a thin corpus callosum. At 18 years of age, he has normal length and weight, and a pronounced macrocephaly ( $>99$ th percentile). Dysmorphic features include a broad and furrowed forehead, wide mouth, tooth anomalies, doughy, soft skin and multiple nevi. Furthermore, he has ID, autism, behavioural problems and has required surgical treatment due to a left-convex thoracic scoliosis (figure 1, table 1).

\section{Genetic findings}

WGS analysis after bioinformatic filtering revealed four sequence variants for clinical review (online supplemental table 2). The 


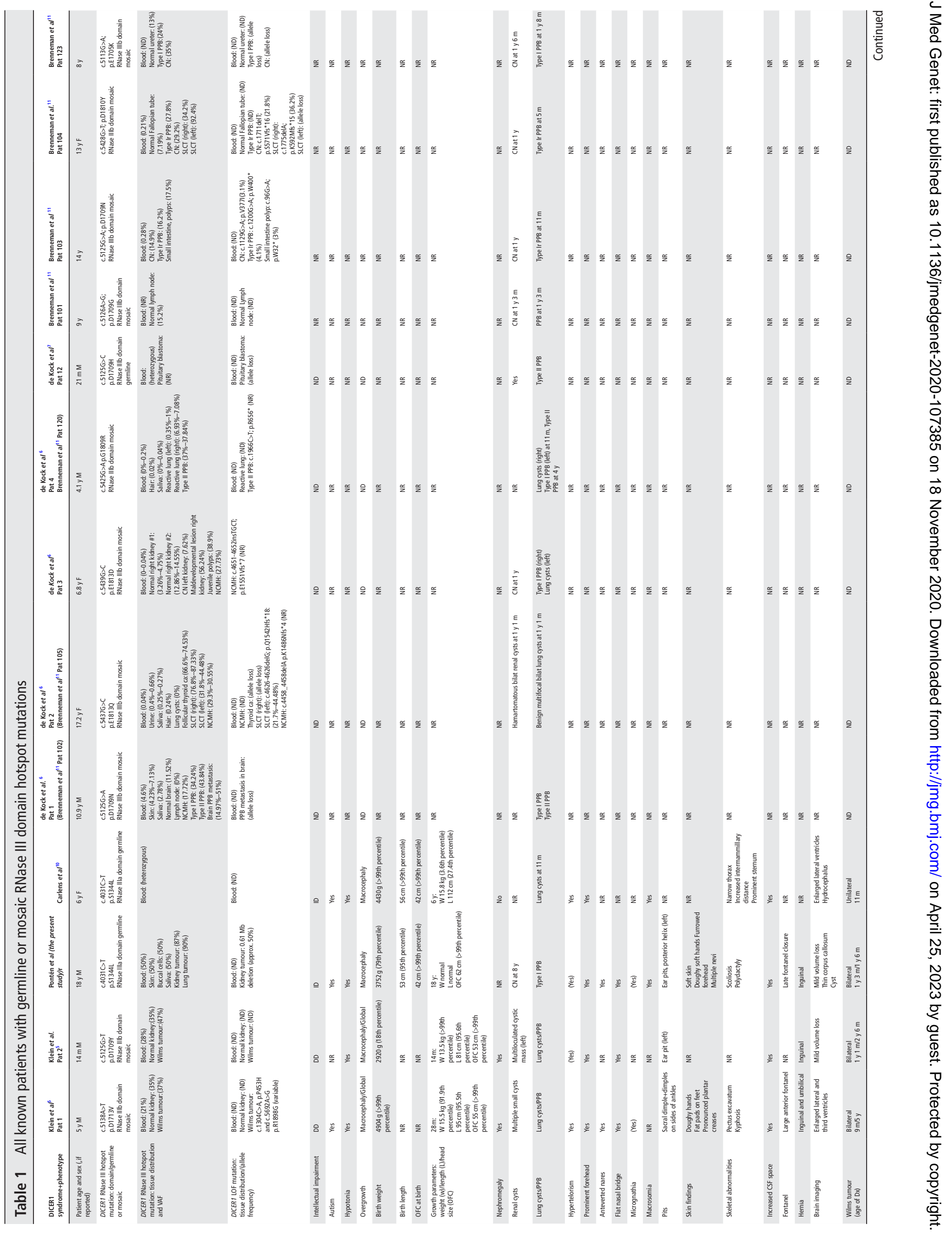




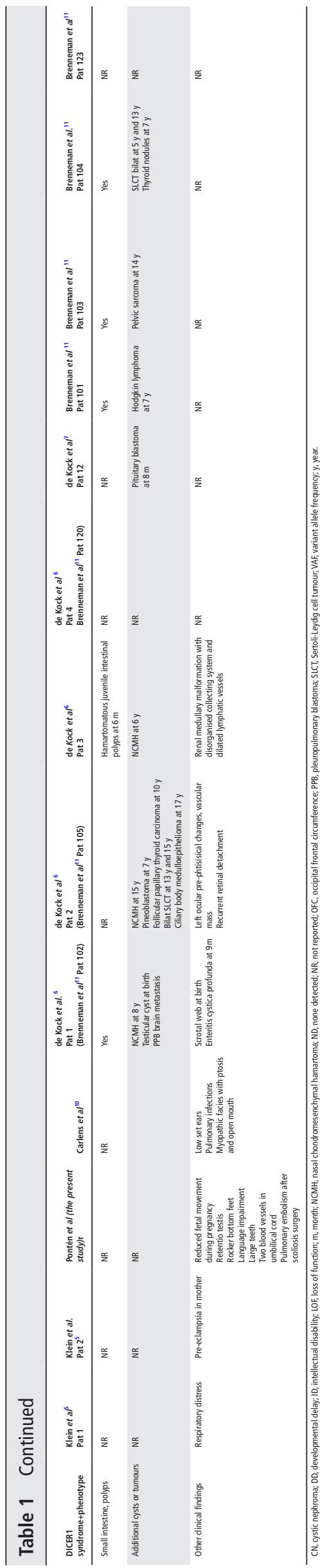

only clinically relevant variant was a heterozygous sequence variant in exon 21 of DICER1; NM_030621.4: c.4031C>T, (p.S1344L). The variant was verified and segregation analysis was performed using Sanger sequencing. Neither of the parents were carriers of this variant (data not shown). Digital PCR was performed on patient-DNA from buccal cells (not shown), saliva (not shown), blood and skin (figure 1), which showed a mutant allelic frequency of $50 \%$ in all samples, thus excluding mosaicism of the mutation. ES of DNA prepared from kidney and lung tumour tissue revealed that the germline heterozygous mutation c.4031C $>\mathrm{T}$ in DICER1 was more abundant in the tumour tissue, $87 \%$ and $90 \%$, respectively. In order to verify loss of heterozygosity $(\mathrm{LOH})$ in the tumour, DNA from the fresh tissue (kidney tumour) was subjected to WGS. WGS data confirmed a $0.61 \mathrm{Mb}$ deletion covering the whole DICER1 gene (Chr14(Hg19): g.95247243 95858197del).

ES of the well-differentiated fetal lung adenocarcinoma revealed distinct tumour-only single nucleotide variants that distinguished it from the Wilms tumour and confirmed its separate nature.

\section{DISCUSSION}

We show that a heterozygous germline mutation c.4031C > T (p.S1344L) in the RNase IIIa domain of DICER1 is compatible with life, and causes a complex 'DICER1 syndrome plus' phenotype with extensive bilateral and multilobar lung cysts, PPB, cystic nephroma, Wilms tumour, well-differentiated fetal lung adenocarcinoma, ID, macrocephaly, ear pits and other physical anomalies. This phenotype closely resembles reported clinical findings of a patient with the identical germline p.S1344L pathogenic variant presented at a paediatric pneumology association meeting in Vienna. ${ }^{10}$ There are also close similarities to the phenotype described in two children with GLOW syndrome and mosaic hotspot mutations in the RNase IIIb domain, ${ }^{5}$ although the postnatal overgrowth was more pronounced in the individuals with GLOW syndrome. Thus, the phenotype of the widely expressed germline RNase IIIa-S1344L variant resembles the extreme end of the phenotypes associated with mosaic hotspot mutations in the sequence encoding the RNase IIIb domain of DICER $1 .{ }^{11}$ This strongly supports previous somatic findings from integrated genetic analysis and in vitro cell experiments in cancer cells, where the RNase IIIa-S1344L mutation functionally perturbs RNase IIIb catalytic activity. ${ }^{24}$ The observation that only a minority of reported germline $(n=1)$ or mosaic $(n=10)$ RNase IIIb mutations are associated with the so-called GLOW phenotype (table 1), suggests that these mutations result in severe but highly pleiotropic phenotypes that cannot be predicted from the genotype. ${ }^{25611}$ It will be important to determine whether, in contrast, RNase IIIa hotspot mutations invariably result in a severe 'DICER1 syndrome plus' phenotype.

In support of a potentially distinct functional consequence of RNase IIIa hotspot mutations, compared with RNase IIIb mutations, RNase IIIa catalytic site mutations are rare in cancers and RNase IIIa-S1344L is the only recurring cancer hotspot mutation that occurs in this domain. To date, p.S1344L mutations have been described in 15 tumours. Interestingly, the types of tumours which develop due to DICER1 hotspot mutations are unevenly distributed among the targeted tissues. In the 15 tumours with p.S1344L in the RNase IIIa domain, there were 4 Wilms tumours, 4 malignant melanomas, 1 Merkel cell carcinoma, 3 endometroid carcinomas, 2 colorectal cancers and 1 cholangiocarcinoma. ${ }^{10}{ }^{12-15}$ Tumours bearing RNase IIIa-S1344L hotspot mutations are most commonly malignant melanomas 
$(4 / 15 ; 27 \%)$ in contrast to tumours bearing hotspot mutations in the RNase IIIb domain $(2 / 318 ; 0.6 \%){ }^{4}{ }^{45}$ This indicates that hotspot mutations in different RNase III domains of DICER1 cause tissue-specific susceptibilities to develop certain tumours.

This is the second well-differentiated fetal lung adenocarcinoma reported in DICER1 syndrome. ${ }^{16-18}$ Here, the diagnosis was made on the basis of glycogen-rich neoplastic glands and tubules resembling fetal lung tissue (at 10-15 weeks gestation). In contrast to biphasic PPB, the adjacent stroma is benign.

In addition to our patient, we identified 27 sequenced Wilms tumours with RNase IIIa or RNase IIIb domain hotspot mutations; in 17 of $28(61 \%)$ there was no alteration on the other allele, while 11 of 28 (39\%) had two mutations. One tumour with a germline RNase IIIa hotspot mutation did not undergo somatic testing (online supplemental table 3). Further studies are needed to determine if the sequenced Wilms tumours that lacked somatic alterations on the other allele could have copy neutral $\mathrm{LOH}$ or a deletion as described in our patient, or other genetic aberrations that escaped detection by the methods used.

Non-tumour-related phenotypes occur in DICER1 syndrome; macrocephaly has recently been described in 28/67 (42\%) of patients with the syndrome in a single study. ${ }^{19}$ General overgrowth is more pronounced in patients with GLOW syndrome, ${ }^{5}$ while patients with RNase IIIa-S1344L mutations only present with macrocephaly. ${ }^{10}$ Recently, Klein et al reported activation of the phosphatidylinositol 3-kinase (PI3K)/AKT/mammalian target of rapamycin (mTOR) pathway in genetically modified cells with hotspot mutations in the RNase IIIlb domain associated with GLOW syndrome. ${ }^{20}$ It is noteworthy that some patients with mutations in the PI3K/AKT/mTOR pathway have overlapping symptoms with our patient, such as polydactyly in patients with mutations in AKT3 or PIK3CA, and multiple nevi, macrocephaly and ID seen in PTEN and PIK3CA-related disorders. Posterior helical pits are rare and have previously been described in Beckwith-Wiedemann syndrome, Simpson-Golabi-Behmel syndrome and GLOW syndrome, all of which are cancer predisposition syndromes with a risk of developing Wilms tumour. In patients with Beckwith-Wiedemann syndrome and CDKN1C mutations, an extended phenotype including ear pits and polydactyly has been described. To date, ID/developmental delay has been reported in at least nine patients with large deletions encompassing several genes including DICER $1,{ }^{21-27}$ and in three patients with RNase IIIb or RNase IIIa-S1344L hotspot mutations. ${ }^{510}$

The highly penetrant and severe phenotypes described in patients with germline or mosaic RNase III domain mutations ${ }^{56}$ may be explained by the likelihood of a second somatic mutation stochastically occurring in any part of DICER1 being greater than the reverse succession normally seen in DICER1 syndrome, in combination with tissue-specific neomorphic effects of the specific heterozygous RNase III domain mutations. ${ }^{11}$

In conclusion, germline RNase IIIa-S1344L pathogenic variants result in a "DICER1 syndrome plus" phenotype that in addition to classic features, also includes ID and ear pits. The conferred phenotype is similar, but not identical to that of early post zygotic DICER1 RNase IIIb hotspot mutations.

Acknowledgements The authors would like to thank the family of the described patient for their participation. Additional results published here are in part based on data generated by the TCGA Research Network: https://www.cancer.gov/tcga.

Contributors AN coordinated the study. AN and KLR performed WGS analyses. NP provided clinical care. SW, SF, WDF, AN and NP performed clinical and pathological phenotyping. SF and FT performed digital PCR. EP, SF, FT, AN, RV, NP, WDF, LdK and KLR contributed with data collection, interpretation and discussion of results. EP and AN wrote the manuscript in consultation with all authors.
Funding This work was supported by grants from the Swedish Childhood Cancer Fund, the Swedish Cancer Society, the Cancer Society of Stockholm, the Swedish Research Council, Berth von Kantzow's Foundation and The Hållsten Research Foundation.

Competing interests WDF reports support from AstraZeneca, outside the submitted work (VUS classification project in breast cancer gene sequencing project).

Patient consent for publication Parental/guardian consent obtained.

Ethics approval The local Ethics Committee at Karolinska Institute approved the study (Dnr 2012-2106-31/4), which followed the tenets of the Declaration of Helsinki. Written informed consent was obtained from the parents.

Provenance and peer review Not commissioned; externally peer reviewed.

Supplemental material This content has been supplied by the author(s). It has not been vetted by BMJ Publishing Group Limited (BMJ) and may not have been peer-reviewed. Any opinions or recommendations discussed are solely those of the author(s) and are not endorsed by BMJ. BMJ disclaims all liability and responsibility arising from any reliance placed on the content. Where the content includes any translated material, BMJ does not warrant the accuracy and reliability of the translations (including but not limited to local regulations, clinical guidelines, terminology, drug names and drug dosages), and is not responsible for any error and/or omissions arising from translation and adaptation or otherwise.

Open access This is an open access article distributed in accordance with the Creative Commons Attribution 4.0 Unported (CC BY 4.0) license, which permits others to copy, redistribute, remix, transform and build upon this work for any purpose, provided the original work is properly cited, a link to the licence is given, and indication of whether changes were made. See: https://creativecommons.org/ licenses/by/4.0/.

\section{ORCID iDs}

Emeli Pontén http://orcid.org/0000-0002-9174-9804

Fulya Taylan http://orcid.org/0000-0002-2907-0235

Leanne de Kock http://orcid.org/0000-0001-7314-1371

William D Foulkes http://orcid.org/0000-0001-7427-4651

Kristina Lagerstedt-Robinson http://orcid.org/0000-0001-9848-0468

Ann Nordgren http://orcid.org/0000-0003-3285-4281

\section{REFERENCES}

1 Foulkes WD, Priest JR, Duchaine TF. DICER1: mutations, microRNAs and mechanisms. Nat Rev Cancer 2014;14:662-72.

2 de Kock L, Wu MK, Foulkes WD. Ten years of DICER1 mutations: Provenance, distribution, and associated phenotypes. Hum Mutat 2019:40:1939-53.

3 Rakheja D, Chen KS, Liu Y, Shukla AA, Schmid V, Chang T-C, Khokhar S, Wickiser JE, Karandikar NJ, Malter JS, Mendell JT, Amatruda JF. Somatic mutations in Drosha and DICER1 impair microRNA biogenesis through distinct mechanisms in Wilms tumours. Nat Commun 2014;2:4802.

4 Vedanayagam J, Chatila WK, Aksoy BA, Majumdar S, Skanderup AJ, Demir E, Schultz $\mathrm{N}$, Sander C, Lai EC. Cancer-Associated mutations in DICER1 RNase IIIA and IIIB domains exert similar effects on miRNA biogenesis. Nat Commun 2019;10:3682.

5 Klein S, Lee H, Ghahremani S, Kempert P, Ischander M, Teitell MA, Nelson SF, Martinez-Agosto JA. Expanding the phenotype of mutations in DICER1: mosaic missense mutations in the RNase IIIB domain of DICER1 cause glow syndrome. J Med Genet 2014:51:294-302.

6 de Kock L, Wang YC, Revil T, Badescu D, Rivera B, Sabbaghian N, Wu M, Weber E, Sandoval C, Hopman SMJ, Merks JHM, van Hagen JM, Bouts AHM, Plager DA, Ramasubramanian A, Forsmark L, Doyle KL, Toler T, Callahan J, Engelenberg C, Bouron-Dal Soglio D, Priest JR, Ragoussis J, Foulkes WD. High-sensitivity sequencing reveals multi-organ somatic mosaicism causing DICER1 syndrome. J Med Genet 2016:53:43-52.

7 de Kock L, Sabbaghian N, Plourde F, Srivastava A, Weber E, Bouron-Dal Soglio D, Hamel N, Choi JH, Park S-H, Deal CL, Kelsey MM, Dishop MK, Esbenshade A, Kuttesch JF, Jacques TS, Perry A, Leichter H, Maeder P, Brundler M-A, Warner J, Neal J, Zacharin M, Korbonits M, Cole T, Traunecker H, McLean TW, Rotondo F, Lepage P, Albrecht S, Horvath E, Kovacs K, Priest JR, Foulkes WD. Pituitary blastoma: a pathognomonic feature of germ-line DICER1 mutations. Acta Neuropatho/ 2014;128:111-22.

8 Karczewski KJ, Francioli LC, Tiao G, Cummings BB, Alföldi J, Wang Q, Collins RL, Laricchia KM, Ganna A, Birnbaum DP, Gauthier LD, Brand H, Solomonson M, Watts NA, Rhodes D, Singer-Berk M, England EM, Seaby EG, Kosmicki JA, Walters RK, Tashman K, Farjoun Y, Banks E, Poterba T, Wang A, Seed C, Whiffin N, Chong JX, Samocha KE, Pierce-Hoffman E, Zappala Z, O'Donnell-Luria AH, Minikel EV, Weisburd B, Lek M, Ware JS, Vittal C, Armean IM, Bergelson L, Cibulskis K, Connolly KM, Covarrubias M, Donnelly S, Ferriera S, Gabriel S, Gentry J, Gupta N, Jeandet T, Kaplan D, Llanwarne C, Munshi R, Novod S, Petrillo N, Roazen D, Ruano-Rubio V, Saltzman A, Schleicher M, Soto J, Tibbetts K, Tolonen C, Wade G, Talkowski ME, Neale BM, Daly MJ, MacArthur DG, Genome Aggregation Database Consortium. The mutational constraint spectrum quantified from variation in 141,456 humans. Nature 2020;581:434-43. 
9 Frisk S, Taylan F, Blaszczyk I, Nennesmo I, Annerén G, Herm B, Stattin E-L, Zachariadis V, Lindstrand A, Tesi B, Laurell T, Nordgren A. Early activating somatic PIK3CA mutations promote ectopic muscle development and upper limb overgrowth. Clin Genet 2019;96:118-25.

10 Carlens J KC, Ahrens F, Griese M, Schwerk N. Zeitschrift der gesellschaft für pädiatrische pneumologie, 2018: 36-41.

11 Brenneman M, Field A, Yang J, Williams G, Doros L, Rossi C, Schultz KA, Rosenberg A, Ivanovich J, Turner J, Gordish-Dressman H, Stewart D, Yu W, Harris A, Schoettler P, Goodfellow P, Dehner L, Messinger Y, Hill DA. Temporal order of RNase IIIb and lossof-function mutations during development determines phenotype in pleuropulmonary blastoma / DICER1 syndrome: a unique variant of the two-hit tumor suppression model. F1000Res 2015;4.

12 Gadd S, Huff V, Walz AL, Ooms AHAG, Armstrong AE, Gerhard DS, Smith MA, Auvil JMG, Meerzaman D, Chen Q-R, Hsu CH, Yan C, Nguyen C, Hu Y, Hermida LC, Davidsen T, Gesuwan P, Ma Y, Zong Z, Mungall AJ, Moore RA, Marra MA, Dome JS, Mullighan CG, Ma J, Wheeler DA, Hampton OA, Ross N, Gastier-Foster JM, Arold ST, Perlman EJ. A children's Oncology group and target initiative exploring the genetic landscape of Wilms tumor. Nat Genet 2017;49:1487-94.

13 Wu MK, Sabbaghian N, Xu B, Addidou-Kalucki S, Bernard C, Zou D, Reeve AE, Eccles MR, Cole C, Choong CS, Charles A, Tan TY, Iglesias DM, Goodyer PR, Foulkes WD. Biallelic DICER1 mutations occur in Wilms tumours. J Pathol 2013;230:154-64.

14 Zehir A, Benayed R, Shah RH, Syed A, Middha S, Kim HR, Srinivasan P, Gao J, Chakravarty D, Devlin SM, Hellmann MD, Barron DA, Schram AM, Hameed M, Dogan S, Ross DS, Hechtman JF, DeLair DF, Yao J, Mandelker DL, Cheng DT, Chandramohan R, Mohanty AS, Ptashkin RN, Jayakumaran G, Prasad M, Syed MH, Rema AB, Liu ZY, Nafa K, Borsu L, Sadowska J, Casanova J, Bacares R, Kiecka IJ, Razumova A, Son JB, Stewart L, Baldi T, Mullaney KA, Al-Ahmadie H, Vakiani E, Abeshouse AA, Penson AV, Jonsson P, Camacho N, Chang MT, Won HH, Gross BE, Kundra R, Heins ZJ, Chen H-W, Phillips S, Zhang H, Wang J, Ochoa A, Wills J, Eubank M, Thomas SB, Gardos SM, Reales DN, Galle J, Durany R, Cambria R, Abida W, Cercek A, Feldman DR, Gounder MM, Hakimi AA, Harding JJ, lyer G, Janjigian YY, Jordan EJ, Kelly CM, Lowery MA, Morris LGT, Omuro AM, Raj N, Razavi P, Shoushtari AN, Shukla N, Soumerai TE, Varghese AM, Yaeger R, Coleman J, Bochner B, Riely GJ, Saltz LB, Scher HI, Sabbatini PJ, Robson ME, Klimstra DS, Taylor BS, Baselga J, Schultz N, Hyman DM, Arcila ME, Solit DB, Ladanyi $\mathrm{M}$, Berger MF. Mutational landscape of metastatic cancer revealed from prospective clinical sequencing of 10,000 patients. Nat Med 2017;23:703-13.

15 Tate JG, Bamford S, Jubb HC, Sondka Z, Beare DM, Bindal N, Boutselakis H, Cole CG, Creatore C, Dawson E, Fish P, Harsha B, Hathaway C, Jupe SC, Kok CY, Noble K, Ponting L, Ramshaw CC, Rye CE, Speedy HE, Stefancsik R, Thompson SL, Wang S, Ward S, Campbell PJ, Forbes SA. Cosmic: the Catalogue of somatic mutations in cancer. Nucleic Acids Res 2019;47:D941-7.
16 de Kock L, Bah I, Wu Y, Xie M, Priest JR, Foulkes WD. Germline and somatic DICER1 mutations in a well-differentiated fetal adenocarcinoma of the lung. J Thorac Oncol 2016;11:e31-3.

17 Wu Y, Chen D, Li Y, Bian L, Ma T, Xie M. DICER1 mutations in a patient with an ovarian Sertoli-Leydig tumor, well-differentiated fetal adenocarcinoma of the lung, and familial multinodular goiter. Eur J Med Genet 2014;57:621-5.

18 Liu S, Wang J, Luo X, Li X, Miao Y, Wang L, Li Q, Qiu X, Wang E-H. Coexistence of low-grade fetal adenocarcinoma and adenocarcinoma in situ of the lung harboring different genetic mutations: a case report and review of literature. Onco Targets Ther 2020;13:6675-80

19 Khan NE, Bauer AJ, Doros L, Schultz KAP, Decastro RM, Harney LA, Kase RG, Carr $A G$, Harris AK, Williams GM, Dehner LP, Messinger YH, Stewart DR. Macrocephaly associated with the DICER1 syndrome. Genet Med 2017;19:244-8.

20 Klein SD, Martinez-Agosto JA. Hotspot mutations in DICER1 causing GLOW Syndrome-associated macrocephaly via modulation of specific microRNA populations results in activation of PI3K/ATK/mTOR signaling. Microrna 2020;9:70-80.

21 de Kock L, Hillmer M, Wagener R, Soglio DB-D, Sabbaghian N, Siebert R, Priest JR, Miller M, Foulkes WD. Further evidence that full gene deletions of DICER1 predispose to DICER1 syndrome. Genes Chromosomes Cancer 2019;58:602-4.

22 Herriges JC, Brown S, Longhurst M, Ozmore J, Moeschler JB, Janze A, Meck J, South ST Andersen EF. Identification of two $14 q 32$ deletions involving DICER1 associated with the development of DICER1-related tumors. Eur J Med Genet 2019;62:9-14.

23 de Kock L, Geoffrion D, Rivera B, Wagener R, Sabbaghian N, Bens S, Ellezam B, Bouron-Dal Soglio D, Ordóñez J, Sacharow S, Polo Nieto JF, Guillerman RP, Vujanic GM, Priest JR, Siebert R, Foulkes WD. Multiple DICER1-related tumors in a child with a large interstitial 14q32 deletion. Genes Chromosomes Cancer 2018; 57:223-30.

24 van Engelen K, Villani A, Wasserman JD, Aronoff L, Greer M-LC, Tijerin Bueno M, Gallinger B, Kim RH, Grant R, Meyn MS, Malkin D, Druker H. Dicer1 syndrome: approach to testing and management at a large pediatric tertiary care center. Pediatr Blood Cancer 2018;65.

25 Zampini L, D'Odorico L, Zanchi P, Zollino M, Neri G. Linguistic and psychomotor development in children with chromosome 14 deletions. Clin Linguist Phon 2012;26:962-74.

26 Ting TW, Brett MS, Cham BWM, Lim J-Y, Law HY, Tan EC, Lai AHM, Jamuar SS. DICER1 deletion and 14q32 microdeletion syndrome: an additional case and a review of the literature. Clin Dysmorphol 2016;25:37-40.

27 Piccione M, Antona V, Scavone V, Malacarne M, Pierluigi M, Grasso M, Corsello G. Array CGH defined interstitial deletion on chromosome 14: a new case. Eur J Pediatr 2010;169:845-51. 